\title{
New quantitative variables to measure postoperative pericardial adhesions. Useful tools in experimental research ${ }^{1}$
}

\author{
Novas variáveis quantitativas para avaliação das aderências pericárdicas. Ferramentas úteis na \\ pesquisa experimental
}

\author{
Jackson Brandão Lopesi, Luís Alberto Oliveira Dallan", Luiz Felipe Pinho Moreira"I, Mário Castro Carreiro ${ }^{\mathrm{III}}$, Flávia Luana \\ Barbosa Rodrigues $^{\text {IV }}$, Pedro de Castro Mendes ${ }^{I V}$, Noedir Antônio Groppo Stolf ${ }^{v}$

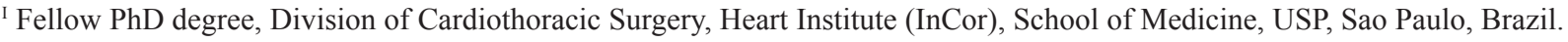

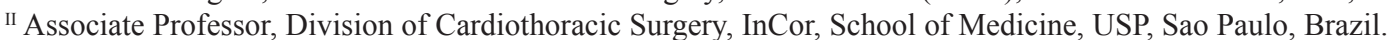 \\ III Associate Professor, Division of Surgical Technique and Experimental Surgery, School of Medicine, Federal University of Bahia (UFBA), Brazil. \\ IV Graduate Student, Vale do Aço Medical School (FAMEVAÇO), Brazil. \\ ${ }^{v}$ Full Professor, Head, Division of Cardiothoracic Surgery, InCor, School of Medicine, USP, Sao Paulo, Brazil.
}

\begin{abstract}
Purpose: To improve the measurement system, during a research for the prevention of adhesions, we explored the feasibility of introducing three continuous numeric variables to quantify the intensity of pericardial adhesions. Methods: To validate these three new numeric variables - time spent to dissect the adhesions $(\Delta t)$, the amount of sharp dissection (ShpD) and the adhesion's collagen area (ACA) - as useful tools in measuring the severity of pericardial adhesions, data from a randomized study on adhesion prevention enrolling twenty-four swine, were analysed. A statistical Spearman's test and regressions models were applied to verify the correlation and the relationship between the results of a standard severity score (SS) and $\Delta \mathrm{t}$, between SS and ShpD used in adhesiolysis and, also, between SS and ACA. Results: There was a statistically significant correlation between SS and $\Delta \mathrm{t}$, between SS and ShpD, as well as between SS and ACA, all measured by the Spearman's test ( $\mathrm{r}=0.897, \mathrm{r}=0.932, \mathrm{r}=0.66 ; \mathrm{p}<0.01$, respectively). Through a non-linear regression, an exponential relation of SS with ShpD $\left(\mathrm{R}^{2}=0.915\right)$ and SS with $\Delta \mathrm{t}\left(\mathrm{R}^{2}=0.917\right)$ was found. Conclusion: The time spent to dissect the adhesions $(\Delta t)$ and the amount of sharp dissection (ShpD) are new powerful measurement tools in evaluating outcomes of the methods used to prevent pericardial adhesions.
\end{abstract}

Key words: Pericardium. Adhesions. Models, Animal. Random Allocation. Statistics, Nonparametric. Thoracic Surgery. Collagen. Swine.

\section{RESUMO}

Objetivo: A fim de melhorar a metodologia de mensuração das aderências pericárdicas, avaliamos, durante um estudo de prevenção de aderências pericárdicas, a possibilidade da utilização de três de novas variáveis contínuas e numéricas. Métodos: Para validar estas novas variáveis numéricas - tempo de dissecção $(\Delta \mathrm{t})$, quantidade de dissecção cruenta $(\mathrm{ShpD})$ e a área de colágeno na aderência $(\mathrm{ACA})$ - como instrumentos precisos na quantificação das aderências pericárdicas, foram analisados os dados de um estudo para prevenção de aderências que envolveu 24 porcos. Foram aplicados modelos de regressão e o teste de Spearman para avaliar a força e os tipos correlações entre os resultados do escore padrão de classificação de aderências (SS) e o $\Delta \mathrm{t}$, entre o SS e o ShpD, e, também, entre o SS e a ACA. Resultados: Foram evidenciadas correlações, estatisticamente significativas, entre o SS e o $\Delta \mathrm{t}$, entre o SS e o ShpD, também como entre o SS e a ACA avaliadas através do teste de Spearman ( $\mathrm{r}=0,897, \mathrm{r}=0,932, \mathrm{r}=0,66 ; \mathrm{p}<0,001$, respectivamente). Identificou-se, através de regreção não-linear, uma relação exponencial do $\mathrm{SS}$ com o $\operatorname{ShpD}\left(\mathrm{R}^{2}=0,915\right)$ e com o $\Delta \mathrm{t}\left(\mathrm{R}^{2}=0,917\right)$. Conclusão: Este estudo mostrou que o $\Delta$ t e o ShpD são variáveis poderosas para avaliar os resultados dos métodos utilizados para prevenção das aderências pericárdicas Descritores: Pericárdio. Aderências. Modelos Animais. Distribuição Aleatória. Estatísticas não Paramétricas. Cirurgia Torácica. Colágeno. Suínos.

${ }^{1}$ Research performed at Cardiopneumology Department, Post-Graduate Program, School of Medicine, University of Sao Paulo (USP), Brazil. 


\section{Introduction}

Postoperative adhesions are formed after surgical cardiac and great vessels procedures, as part of the healing process. The scar tissue makes the re-entry complex, increasing the rate of iatrogenic lesions. ${ }^{1-3}$

Currently, as reoperations represent 10 to $20 \%$ of heart surgeries, ${ }^{1,4,5}$ various methods have been investigated to prevent or decrease the severity of postoperative adhesions. ${ }^{6-8}$

Since $1968,{ }^{6}$ the current way to evaluate the outcome of methods used in preventing pericardial adhesions is grading the severity of the adhesions, using a subjective scale. Improvements in the measurement method were, already, done by clarifying the proper definitions of scale ranks. But yet, there isn't a consensus among grading scales, ${ }^{7,9-12}$ causing a challenge when there's a need to compare study results.

In a way to improve the measurement system, we explored the feasibility of introducing three continuous numeric variables to quantify the intensity of pericardial adhesions, during a research for prevention of adhesions.

\section{Methods}

In trying to determine the feasibility of using the three new numeric variables in evaluating the severity of pericardial adhesions, the results of a classical subjective severity score (Table 1) were compared with the time used in dissection and with the amount of sharp dissection used during the reoperation. For this purpose all three variables were collected from a randomized pericardial prevention assay that used twenty-four male large-white swine. The ethics committee of the Heart Institute, University of São Paulo, approved the study protocol. All animals received human care in compliance with the "Guide for Care and Use of Laboratory Animals" published by National Institutes of Health (NIH publication 85-23, revised 1996) and ethic principles on animal research established by the Brazilian College of Animals Research (COBEA) were followed.

TABLE 1 - Grading adhesions severity

\begin{tabular}{cl}
\hline $\begin{array}{c}\text { Adhesion } \\
\text { Grade }\end{array}$ & \multicolumn{1}{c}{ Description } \\
\hline $\mathbf{0}$ & Without adhesions. \\
I & Filmy, light, with a foamy dissection plane without bleeding. \\
II & $\begin{array}{l}\text { Required some sharp dissection but most of them were } \\
\text { lyzed by digital manipulation. This process resulted in a } \\
\text { moderate bleeding. }\end{array}$ \\
III & $\begin{array}{l}\text { Dense, easily bleeding, with marked obliteration of tissue } \\
\text { planes and required exclusive sharp dissection. }\end{array}$ \\
\hline
\end{tabular}

\section{Surgical protocol}

Anaesthesia was induced with an intramuscular injection of ketamine hydrochloride $(10 \mathrm{mg} / \mathrm{kg})$ and atropine $(0.05 \mathrm{mg} / \mathrm{kg})$. A prophylactic dose of penicillin-streptomycin based veterinary antibiotic was administered. A venous line was established in the ear and a saline solution was infused at a rate of $3 \mathrm{ml} / \mathrm{kg} / \mathrm{h}$. Endotracheal intubation was performed after a venous bolus of thiopental sodium $(10 \mathrm{mg} / \mathrm{kg})$ and phentanyl $(0.05 \mu \mathrm{g} / \mathrm{kg})$. Artificial respiration was obtained with a volume-control ventilator. Anaesthesia was maintained with $0.5-2 \%$ isoflurane.

After standard skin preparation, a right thoracotomy was performed. A pericardiotomy, anterior to the phrenic nerve, was made to expose the heart. The epicardium and parietal pericardium - related to right atrium, right and left ventricle - were abraded with a $1.5 \times 1.0 \mathrm{~cm}$ sandpaper in ten manual movements. Polyester 2.0 sutures were performed in the aorta and right atrium and then tied. The pericardial cavity was covered with $20 \mathrm{ml}$ of autologous blood and after thirty minutes the clots were aspirated. A fenestrated catheter was inserted through a small pericardial orifice and the cavity was closed with a running suture.

The surgical team injected, through the catheter, $1 \mathrm{ml} / \mathrm{kg}$ of a solution containing the randomized drug: saline, carboxymethylchitosan 3,2\%, keratinocyte growth factor $(22 \mathrm{ng} / \mathrm{ml}$ ) or carboxymethylchitosan associated to the keratinocyte growth factor. A thoracic drain was placed to evacuate the air in the pleural cavity, and the chest was closed in three layers. The anaesthetic gas was suspended and the animals were allowed to wake up. The postoperative analgesia was obtained with intramuscular doses of morphine sulphate $(0.2 \mathrm{mg} / \mathrm{kg})$. 


\section{Reoperation}

Eight weeks after the initial procedure, following the same anaesthesia protocol, the animals were submitted to a median sternotomy. The adhesion formation was evaluated in six intrapericardial areas: in anterior, lateral and inferior ventricular surfaces, in the right atrial suture, in the aortic suture and in the pericardial suture line. A blinded observer graded these areas using a scale system: Grade 0 indicated that adhesions didn't exist; grade 1 adhesions were filmy, light, with a foamy dissection plane; grade 2 were intermediate adhesions that required some sharp dissection but most of them were lyzed by digital manipulation; grade 3 adhesions were dense, bleeding easily, with marked obliteration of tissue planes and required solely sharp dissection.

The severity score was defined as the sum of adhesions grades in examined areas. One score was established to each animal.

The time spent in dissection was measured with a digital chronometer. Also, the reoperation was recorded continuously, in two angles, by two digital cameras to quantify how many times the use of a sharp dissection instrument was necessary. After the procedure, the images were reviewed, and the scissors cutting movements were counted. The average of the sharp movements, registered by the two cameras, was defined as the amount of sharp dissection.

At the end of the procedure the animals were euthanized with overdoses of thiopental sodium and a bolus of $19.1 \%(\mathrm{w} / \mathrm{v})$ potassium chloride.

An in-block fragment was obtained from the mid-distance between the superior and inferior cava vena and was immersed in $10 \%(\mathrm{w} / \mathrm{v})$ formaldehyde. This tissue section was formed by the atrial wall, the adhesion tissue and parietal pericardium.

\section{Light microscopic examination}

Fixed histological specimens were embedded in paraffin, sectioned into $5 \mu \mathrm{m}$ and stained with Sirius Red. ${ }^{13,14}$ Sections were examined under microscopic light using $\times 5$ magnifying objective. Images were digitalized using a digital video camera with a $768 \times 576$ (vertical $\times$ horizontal) pixels resolution. Pixel size was converted into micrometers and image analysis was performed using a image analysis software (Leica Quantimet Q500MC, Cambridge, UK).

The morphometric evaluation consisted in the measurement of the collagen stained area into the adhesion segment.

\section{Statistical analysis}

Categorical variables are listed as median (max.-min.), and continuous are listed as mean \pm standard deviation. The data analysis was performed with a GraphPad Prism, 5.01 version. Kruskall-Wallis' test and Dunn's post-test were used to compare adhesion scores. The time used to dissect, the amount of sharp dissection and the histological parameters were evaluated by one-way ANOVA and Bonferroni's post-test. The Spearman's test was utilized as a non-parametric correlation test. A non-linear regression was applied to evaluate the relation between the adhesion score and the dissection time and the amount of sharp dissection. Statistical significance was achieved at $\mathrm{p}<0.05$.

\section{Results}

There were significant correlations between the adhesion score and the dissection time (Spearman's R=0.897 [95\% CI 0.758 to 0.958$] ; \mathrm{p}<0.0001)$ and between the adhesion score and the amount of sharp dissection required to release the heart (Spearman's $\mathrm{R}=0.932$ [95\% CI 0.836 to 0.972 ]; $\mathrm{p}<0.0001$ ). Likewise, there was a significant correlation, although weaker than the formers, between the adhesion score and the area of Sirius Red stained collagen (Spearman's $\mathrm{R}=0.662$ [95\% CI 0.332 to 0.847 ]; $\mathrm{p}<0.0006$ ). The non-linear regression identified an exponential relation of the adhesion severity with the requirement of sharp instrument use $\left(\mathrm{R}^{2}=0.915\right)$ (Figure 1$)$. The same relation was shown between the adhesion severity score and time spent in dissection $\left(\mathrm{R}^{2}=0.917\right)$ (Figure 2).

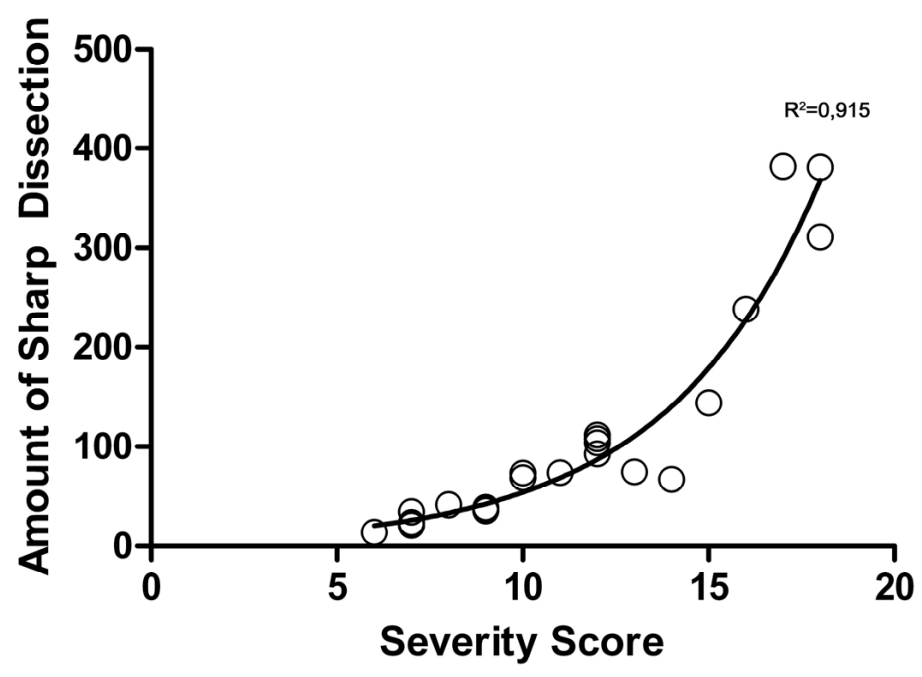

FIGURE 1 - Exponential relationship between the adhesion score and the amount of sharp dissection performed in adhesiolysis

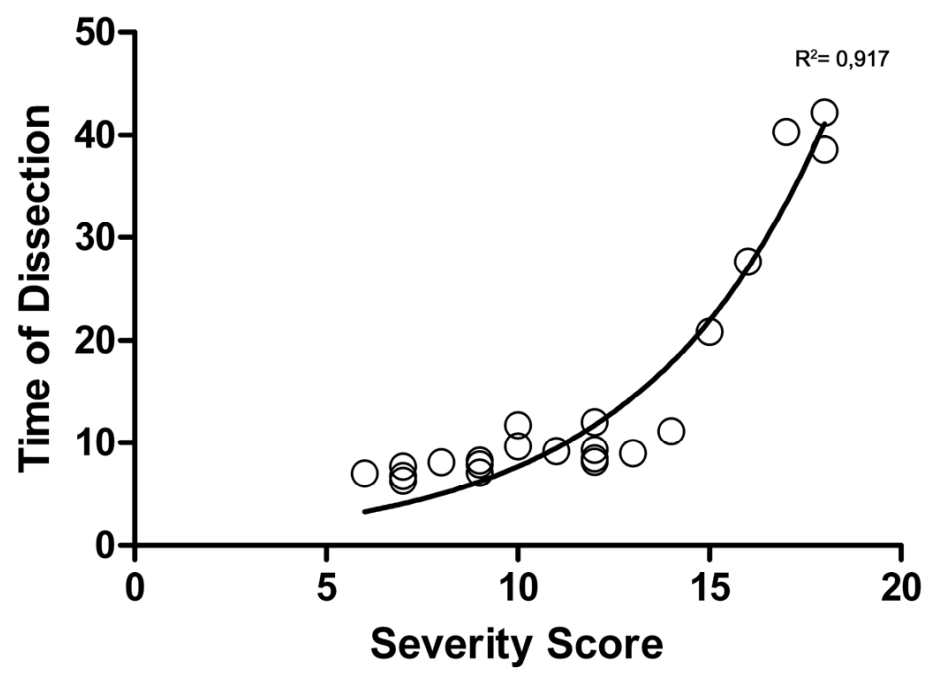

FIGURE 2 - Exponential relationship between the adhesion score and the time used in dissection 


\section{Discussion}

Presently, redo surgeries are common and could reach $20 \%$ of all heart surgeries. ${ }^{1,15}$ Between 1980 and 1999, 22.8\% of all valve surgery registered at the Heart Institute of São Paulo University were reoperations. An estimate of 50,000 re-entries are performed in the USA ${ }^{16}$ every year. Increased morbid-mortality and technical difficulties in these procedures have challenged surgeons. . $^{817,18}$ A 50\% mortality rate has been described, when a major haemorrhage or coronary bypass graft lesions occurs. ${ }^{2,15,19}$ Furthermore, pericardial adhesions can reduce the right ventricle function ${ }^{1,20}$ and the patency of vascular grafts. ${ }^{21,22}$

Currently, although some surgeons use innovative methods to deal with re-entry, ${ }^{23}$ these procedures are, so far, cumbersome and time consuming. Hence, researchers are continuously exploring alternatives for prevention.

Various methods have been investigated to prevent postoperative adhesions. Autologous ${ }^{24}$ and heterologous pericardium, ${ }^{25}$ anti-inflammatory ${ }^{5}$ and fibrinolytic drugs, ${ }^{26}$ synthetic $^{27,28}$ and biopolymers ${ }^{8}$ are examples of therapies employed in these researches. But even with a large number of studies, none of them developed an alternative to improve the problems related to the way in which adhesions are measured. Most of them still base the method outcomes using a subjective scale, built on a categorical variable. This study presented new possibilities to evaluate pericardial adhesions, by introducing three continuous and numeric variables.

There is a common sense that a reoperative procedure takes more time than a surgery performed on a virgin field. Therefore, some surgical centers use a differentiated schedule for those procedures, booking extra time for the operating theatre. Obviously, a longer journey is the reflex of the difficulties imposed by the adhesiolysis, but there's no clear link between the variation of the adhesions' degree and the time spent in redo surgeries. This study showed that the time spent to release the heart is highly correlated with adhesion severity scores and also demonstrated that the relationship is exponential.

Likewise the time of dissection, the amount of sharp movements used during the dissection process is related with the intensity of pericardial adhesions, as demonstrated here by a strong correlation with the adhesion severity score. Like in the previous variable, this relationship also showed to be exponential.

Both findings shown above tell us objectively that the more intense the fibrotic process during the re-entry, the longer and hazardous the surgery will be, and complications will probably occur more often.

The correlation between the collagen area and the severity score wasn't as intense as the two others variables reported previously. Technically, this could be explained because the histological analysis was restricted to a small piece of the right atrium, while the adhesion severity score covered six surface areas of the heart. As a comparison, it would be like looking at one tree and expecting to see and understand what happens in the whole forest.

Other studies should explore the construction of continuous/numeric score using collagen morphometric data. They can also investigate the correlations between the histological score and the other variables: the current subjective score, time of dissection and the amount of sharp dissection.

\section{Conclusion}

The surgical time spent in the adhesiolysis procedure and amounts of sharp dissection are new powerful measurement tools to evaluate the outcomes of methods used to prevent pericardial adhesions. They can be an improvement to the methodology and statistical analysis currently used in this research area.

\section{References}

1. Nkere UU, Whawell SA, Sarraf CE, Schofield JB, Thompson JN, Taylor KM. Perioperative histologic and ultrastructural changes in the pericardium and adhesions. Ann Thorac Surg. 1994;58:437-44.

2. Loop FD. Catastrophic hemorrhage during sternal reentry. Ann Thorac Surg. 1984;37:271-2

3. Dobell AR, Jain AK. Catastrophic hemorrhage during redo sternotomy. Ann Thorac Surg. 1984;37:273-8.

4. Hunter S, Smith GH, Angelini GD. Adverse hemodynamic effects of pericardial closure soon after open heart operation. Ann Thorac Surg. 1992;53:425-9.

5. Vander Salm TJ, Okike ON, Marsicano TH, Compton C, Espinoza E. Prevention of postoperative pericardial adhesions. An animal study. Arch Surg. 1986;121:462-7.

6. Smith LO, Jr. Prevention of surgically induced pericardial adhesions with combined dexamethasone and promethazine therapy. J Fla Med Assoc. 1968;55:413-7.

7. Iliopoulos J, Cornwall GB, Evans RO, Manganas C, Thomas KA, Newman DC, Walsh WR. Evaluation of a bioabsorable polylactide film in a large animal model for the reduction of retrosternal adhesions. J Surg Res. 2004; 118:144-53.

8. Seeger JM, Kaelin LD, Staples EM, Yaacobi Y, Bailey JC, Normann S, Burns JW, Goldberg EP. Prevention of postoperative pericardial adhesions using tissue-protective solutions. J Surg Res. 1997;68:63-6.

9. Chang Y, Lai PH, Wang CC, Chen SC, Chang WC, Sung HW. Mesothelium regeneration on acellular bovine pericardia loaded with an angiogenic agent (ginsenoside Rg1) successfully reduces postsurgical pericardial adhesions. J Thorac Cardiovasc Surg. 2006;132:867-74.

10. Kajihara N, Eto M, Oishi Y, Boku N, Kuwahara K, Nishiguchi N, Kotani C, Morita S. Three-layered synthetic pericardial substitutes reduce postoperative pericardial adhesions. J Thorac Cardiovasc Surg. 2005;129:18-24.

11. Tsukihara H, Takamoto S, Kitahori K, Matsuda K, Murakami A, Novick RJ, Suematsu Y. Prevention of postoperative pericardial adhesions with a novel regenerative collagen sheet. Ann Thorac Surg. 2006;81:650-7.

12. Yoshioka I, Saiki Y, Sakuma K, Iguchi A, Moriya T, Ikada Y, Tabayashi K. Bioabsorbable gelatin sheets latticed with polyglycolic acid can eliminate pericardial adhesion. Ann Thorac Surg. 2007;84:864-70.

13. Borges LF, Taboga SR, Gutierrez PS. Simultaneous observation of collagen and elastin in normal and pathological tissues: analysis of Sirius-red-stained sections by fluorescence microscopy. Cell Tissue Res. 2005;320:551-2.

14. Dantas Filho AM, Aguiar JL, Rocha LR, Azevedo IM, Ramalho E, Medeiros AC. Effects of the basic fibroblast growth factor and its anti-factor in the healing and collagen maturation of infected skin wound. Acta Cir Bras 2007;22:64-71.

15. Duncan DA, Yaacobi Y, Goldberg EP, Mines M, O'Brien D, Congdon F, Carmichael MJ. Prevention of postoperative pericardial adhesions with hydrophilic polymer solutions. J Surg Res. 1988;45:44-9.

16. Mayfield WR. Endoscopic repeat sternotomy. Heart Surg Forum. 1998;1:26-9.

17. Bennett SL, Melanson DA, Torchiana DF, Wiseman DM, Sawhney AS. Next-generation hydrogel films as tissue sealants and adhesion barriers. J Card Surg. 2003;18:494-9. 
18. Garrett HE Jr, Matthews J. Reoperative median sternotomy. Ann Thorac Surg. 1989;48:305.

19. von Segesser L, Jornod N, Faidutti B. Repeat sternotomy after reconstruction of the pericardial sac with glutaraldehyde-preserved equine pericardium. J Thorac Cardiovasc Surg. 1987;93:616-9.

20. Bailey LL, Ze-jian L, Schulz E, Roost H, Yahiku P. A cause of right ventricular dysfunction after cardiac operations. J Thorac Cardiovasc Surg. 1984;87:539-42.

21. Shapira N, Gordon CI, Lemole GM. Occlusion of aortocoronary vein grafts in association with bovine pericardium. Am J Cardiovasc Pathol. 1990;3:87-90.

22. Urschel HC, Jr., Razzuk MA, Gardner M. Coronary artery bypass occlusion second to postcardiotomy syndrome. Ann Thorac Surg. 1976;22:528-31.

23. Mejia R, Saxena P, Tam RK. Hydrodissection in redo sternotomies. Ann Thorac Surg. 2005;79:363-4.

24. Milgalter E, Uretzky G, Siberman S, Appelbaum Y, Shimon DV,
Kopolovic J, Cohen D, Jonas H, Appelbaum A, Borman JB. Pericardial meshing: an effective method for prevention of pericardial adhesions and epicardial reaction after cardiac operations. J Thorac Cardiovasc Surg. 1985;90:281-6.

25. Gallo JI, Artinano E, Duran CM. Clinical experience with glutaraldehydepreserved heterologous pericardium for the closure of the pericardium after open heart surgery. Thorac Cardiovasc Surg. 1982;30:306-9.

26. Smaniotto B, Biondo-Simões MdLP, Artigas GV, Silva AdPGd, Collaço LM, Ramasco GV. Effect of streptokinase in the prevention of intraabdominal adhesions in the rat. Acta Cir Bras. 1997;12:240-5.

27. Laks H, Hammond G, Geha AS. Use of silicone rubber as a pericardial substitute to facilitate reoperation in cardiac surgery. J Thorac Cardiovasc Surg. 1981;82:88-92.

28. Minale C, Nikol S, Hollweg G, Mittermayer C, Messmer BJ. Clinical experience with expanded polytetrafluoroethylene Gore-Tex surgical membrane for pericardial closure: a study of 110 cases. J Card Surg. 1988;3:193-201.

Conflict of interest: none Financial source: none

\section{Correspondence:}

Jackson Brandão Lopes

Rua Jequitibá, 491/302

35.160-306 Ipatinga - MG, Brazil

Phone: (55 31)8824-0465

jackson.lopes@incor.usp.br

Received: October 15, 2008

Review: December 17, 2008

Accepted: January 20, 2009

\section{How to cite this article}

Lopes JB, Dallan LAO, Moreira LFP, Carreiro MC, Rodrigues FLB, Mendes PC, Stolf NAG. New quantitative variables to measure postoperative pericardial adhesions. Useful tools in experimental research. Acta Cir Bras. [serial on the Internet] 2009 Mar-Apr;24(2). Available from URL: http://www.scielo.br/acb 